\title{
EFFECTS OF METFORMIN ON BIOCHEMICAL MARKER OF RECURRENCE AMONG POST MASTECTOMY FEMALE DIABETIC PATIENTS
}

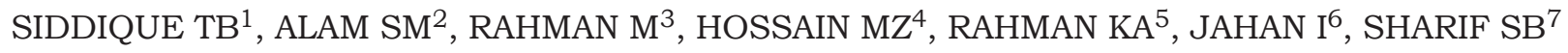

\begin{abstract}
Background: The different modalities of the treatment of diabetes such as life style modification, metformin, insulin and combination of metformin \& insulin have role on breast cancer outcome. Insulin and metformin have some influence on the outcome indirectly by affecting some biochemical markers such as S. adiponectin, HOMA IR \& IGF-I. Therefore this study investigates the effect of metformin and insulin in postsurgical breast cancer patients which is evaluated by S. adiponectin levels and their association with obesity.
\end{abstract}

Objectives: To evaluate effects of metformin on biochemical marker of recurrence among post mastectomy female diabetic patients.

Materials and methods: It was a retrospective cohort study done in Sir Salimullah Medical College and Mitford Hospital Dhaka, from January 2015 to December 2015. In this study purposive consecutive samples were collected at base line from 3 months to 36 months post mastertomy. After fulfill all exclusion and inclusion criteria, 82 cases were selected as sample.

Results: Mean age was found 47.2 years with ranging from 26 to 75 years. Only 9(11.0\%) respondents had family history. The mean BMI was $28.4 \mathrm{~kg} / \mathrm{m}^{2}$ - and mean waist circumference was $95.2 \mathrm{~cm}$. Almost half (48.8\%) respondents took oral contraceptive pill and post menopausal status was found in $48(58.5 \%)$ respondents. The mean $S$. adiponectin level was statistically significant when compared with different type of DM treatment and different BMI group.

Conclusion: This study finally focused that the effects of metformin; the antidiabetic medication has play an important role to change the S. adiponectin level which modify the outcome among post mastectomy diabetic patients. The recurrence can't be evaluated clinically due to short period of time and need a further study for follow up.

Key words: Breast cancer, metformin, S. adiponectin, recurrence.

J Dhaka Med Coll. 2018; 27(1) : 41-46

\section{Introduction:}

Breast cancer is the second most common cancer in the world with an estimated 1.67 million new cancer cases in $2012(25 \%$ of all cancers). Incidence rates vary nearly four-fold across the world regions, with rates ranging from 27 per 100,000 in Middle Africa and Eastern Asia to 96 in Western Europe. Breast cancer ranks as the fifth cause of death from all cancer death $(522,000$ deaths) and it is the most frequent cause of cancer death in women in less developed regions $(324,000$ deaths,
$14.3 \%$ of total) ${ }^{1}$. According to a recent report of the World Health Organization (WHO), nearly 10.50 crore women are affected around the world by cancer each year. Most of them are residing in the third world countries, including Bangladesh. The WHO report also revealed that breast cancer topped the list of the women affected with various types of cancers in Bangladesh $^{2}$. In Bangladesh, the rate of breast cancer occurrence is estimated to be 22.5 per 100,000 females of all ages ${ }^{1}$. NICRH cancer registry report 2008-2010 reveals that breast

1. Dr. Tasnim Binta Siddique, Registrar, Anower Khan Modern Medical College and hospital, Dhaka

2. Dr. Syed Mahbubul Alam, Professor and Ex head of the department of surgery, SSMC\&MH, Dhaka

3. Dr. Mizanur Rahman, Professor of urology, DMCH, Dhaka

4. Dr. Mohammad Zaid Hossain, Associate Professor, Department of Medicine, Dhaka Medical College

5. Dr. Kazi Afzalur Rahman, Associate Professor, Department of Pharmacology, Dhaka Medical College, Dhaka

6. Dr. Ishrat Jahan, Associate professor, department of surgery, SSMC\&MH, Dhaka

7. Dr. Sayeed Bin Sharif, Assistant professor surgery, Khwaja Younus Ali Medical College \& Hospital.

Correspondence : Dr Tasnim Binta Siddique, E-mail:dr.ssmc_2004@yahoo.com, Mobile: 01711464336 
cancer is the leading cancer among the women (26 per cent) and death due to breast cancer is about $10.9 \%$ of the total cancer deaths in Bangladesh ${ }^{3}$.

Treatment of early breast cancer will usually involve surgery with or without radiotherapy. Systemic therapy such as chemotherapy or hormone therapy is available. Surgery still has a central role to play in the management of breast cancer ${ }^{4}$. The incidence of local recurrence correlates with tumor size, presence and number of involved axillary lymphnode, the histologic type of tumor, the presence of skin oedema or skin or fascia fixation with primary tumor, hormonal receptor (ER, PR) and type of definitive surgery and local irradiation, chemotherapy and other targeted therapy. Recurrence also depends on some other associated illness such as diabetes mellitus, hypertension and obesity $5,6,7$.

Among the associated illness, diabetes mellitus is one of the most common metabolic disease worldwide which is linked to an increased risk of developing breast cancer but an even higher risk of recurrence and dying from this disease ${ }^{8}$. Metformin is an oral biguanide that inhibit hepatic gluconeogenesis and sensitizes insulin action at peripheral level. It is the first line treatment of type- 2 diabetes mellitus and can substantially reduce diabetic incidence in obese women with glucose intolerance with a good tolerability profile and low cost9,10. Metformin may have different mechanism of tumor inhibition via insulin- dependent and insulinindependent pathways including activation of adenosine mono-phosphate-activated protein kinase (AMPK) through liver kinase B1 and ataxia teleangiectasia-mutated gene kinase, with inhibition of cancer proliferation and apoptosis induction in breast cancer cell lines $11,12,13,14,15,16$. Other non-cancer medication may potentially have effect on breast cancer prognosis and also survival ${ }^{17}$. Alternatively insulin may promote tumorigenesis via a direct effect on epithelial tissues or indirectly by affecting other modulator such as IGF-1, sex hormones and adipokines 18,19 .

Another study has suggested that breast cancer is associated with insulin resistance and adipokinase leve1 $20,21,22,23,24,25,26,27,28$. Also obesity is commonly associated with hyperinsulinemia, insulin resistance and alterations in levels of adipokines such as S. adiponectin, all of which are associated with an increased risk of developing pre- and postmenopausal breast cancer and recurrence or death in those patients $29,30,31,32$.

So this study will investigate whether the metformin and insulin have really any effective modulation in diabetic breast cancer patients in post surgical trial which can significantly change S. adiponectin level. The patients, who will have changed the level of S. adiponectin, need further investigation to see any type of recurrence by ultrasonogram, CT scan and Bone scan.

\section{Materials and methods:}

This was a retrospective cohort study done from January 2015 to December 2015. Study was conducted in selected Government and Private Hospitals, Dhaka. All post mastectomy female patients having type 2 diabetes mellitus who were treated by different modalities of treatment such as life style modification, metformin, insulin and combined insulin and metformin.

\section{Inclusion criteria:}

All mastectomy female patients having type 2 diabetes mellitus irrespective of age included in the study -

- up to stage IIIa of TNM classification

- who have tumor clearance margin

- at least 3 months of post mastectomy

- who are willing to participate

Exclusion criteria: Diabetic breast cancer patients -

- with distant metastasis

- treated with other than surgery

- with pregnancy 
- with other metabolic and hormonal diseases

- with chronic kidney disease

Data was collected by using a standardized questionnaire. Height and waist circumference (WC) were measured by measuring tape and weight by weighing machine and the values were recorded in the checklist. Generalized obesity was determined by BMI and central obesity by WC. WC was measured by a tape placing horizontally midway between the two points of lowest rib margin and the top of the iliac crest. And the central obesity was defined as WC e" 90th percentile for age and gender (established based on the BCAM study) and categorized as per WHO Guideline for Asian populations.

After fulfilling of all the criteria, diabetic post mastectomy patients bought under plan for measurement of following biochemical markers such as fasting blood glucose and S. adiponectin,. After 8 to 10 hour overnight fast, a fasting blood sample was collected with expert technician in aseptic precaution and sent to the laboratory for biochemical test. Plasma glucose level was measured by the glucose oxidase method, and S. adiponectin by ELISA (Enzyme Linked Immunosorbent Assay). Serum biochemical markers were monitored after getting of insulin and metformin following simple mastectomy with completion of Adjuvant Therapy (chemo/radiotherapy).

All data was expressed as the frequency, percentage and mean $\pm \mathrm{SD}$ as appropriate. Statistical analyses were carried out by using the Statistical Package for Social Sciences version 17.0 for Windows (SPSS Inc., Chicago, Illinois, USA). The quantitative observations were indicated by frequencies and percentages. The mean values were calculated for continuous variables. Unpaired t-test and ANOVA test was used for statistical analysis.
Observation and Results:

Table I

Socio-demographic distribution of the respondents $(n=82)$

\begin{tabular}{ccc}
\hline Age Groups (years) & $\begin{array}{c}\text { Number of } \\
\text { respondents }\end{array}$ & $\begin{array}{c}\text { Percentage } \\
(\%)\end{array}$ \\
\hline $25-34$ & 8 & 9.8 \\
$35-44$ & 21 & 25.6 \\
$45-54$ & 35 & 42.7 \\
$55-64$ & 15 & 18.3 \\
>65 & 3 & 3.7 \\
Family history & & \\
Present & 9 & 11.0 \\
Absent & 73 & 89.0 \\
\hline
\end{tabular}

Table showed that majority $(42.7 \%)$ respondents belonged to age 45-54 years, and mean age was 47.2 years with ranging from 26 to 75 years. Only $9(11 \%)$ respondents had positive family history.

Table II

Anthropometric distribution of the respondents $(n=82)$

\begin{tabular}{ccc}
\hline BMI $\left(\mathrm{kg} / \mathrm{m}^{2}\right)$ & $\begin{array}{c}\text { Number of } \\
\text { respondents }\end{array}$ & $\begin{array}{c}\text { Percentage } \\
(\%)\end{array}$ \\
\hline$<18.5$ & 1 & 1.2 \\
$18.5-24.9$ & 19 & 23.2 \\
$25.0-29.9$ & 42 & 51.2 \\
$\quad \geq 30.0$ & 20 & 24.4 \\
Waist Circumference $(\mathrm{cm})$ & \\
Normal $(<90 \mathrm{~cm})$ & 5 & 6.1 \\
Obese $(>90 \mathrm{~cm})$ & 77 & 93.9 \\
\hline
\end{tabular}

Table II shows that more than half (51.2\%) of the respondents were overweight $\left(25.0-30.0 \mathrm{~kg} / \mathrm{m}^{2}\right)$, mean BMI was found $28.4 \pm 7.7 \mathrm{~kg} / \mathrm{m}^{2}$ - with ranging from 16.7 to $78.2 \mathrm{~kg} / \mathrm{m}^{2}$. Normal $(<90$ $\mathrm{cm})$ waist circumference was found in $5(6.1 \%)$ respondents; mean waist circumference was found $95.2 \pm 15.7 \mathrm{~cm}$ with ranging from 66 to $191 \mathrm{~cm}$.

Table III

Values of the biochemical marker according to the age group of the respondents $(n=82)$

\begin{tabular}{lcccccc}
\hline Biochemical Marker & \multicolumn{5}{c}{ Age Groups (years) } & P \\
\cline { 2 - 6 } & $25-34$ & $35-44$ & $45-54$ & $55-64$ & $>65$ & value \\
& $(\mathrm{n}=8)$ & $(\mathrm{n}=21)$ & $(\mathrm{n}=35)$ & $(\mathrm{n}=15)$ & $(\mathrm{n}=3)$ & \\
& Mean $\pm \mathrm{SD}$ & Mean $\pm \mathrm{SD}$ & Mean $\pm \mathrm{SD}$ & Mean $\pm \mathrm{SD}$ & Mean $\pm \mathrm{SD}$ & \\
\hline S. adiponectin $(\mu \mathrm{g} / \mathrm{ml})$ & $9.3 \pm 0.6$ & $9.1 \pm 0.5$ & $9.1 \pm 0.7$ & $9.1 \pm 0.6$ & $9.5 \pm 0.3$ & 0.899 \\
\hline
\end{tabular}

$\mathrm{P}$ value reached from ANOVA test 
It was observed that mean S. adiponectin level was not significant when compared in different age groups.

\section{Table IV}

Values of biochemical marker according to BMI in respondents $(n=82)$

\begin{tabular}{lcccc}
\hline Biochemical marker & \multicolumn{3}{c}{ BMI $\left(\mathrm{kg} / \mathrm{m}^{2}\right)$} & P \\
\cline { 2 - 5 } & $\begin{array}{c}18.5-24.9 \\
(\mathrm{n}=19) \\
\text { Mean } \pm \text { SD }\end{array}$ & $\begin{array}{c}25-29.9 \\
(\mathrm{n}=42) \\
\text { Mean } \pm \text { SD }\end{array}$ & $\begin{array}{c}\geq 30.0 \\
(\mathrm{n}=20) \\
\text { Mean } \pm \mathrm{SD}\end{array}$ & value \\
\hline S. adiponectin $(\mu \mathrm{g} / \mathrm{ml})$ & $9.62 \pm 0.19$ & $9.25 \pm 0.44$ & $8.36 \pm 0.42$ & 0.001 \\
\hline
\end{tabular}

$\mathrm{P}$ value reached from ANOVA test

Table showed that mean S. adiponectin was significantly lower in BMI e"30 kg/m².

Table V

Values of biochemical marker according to waist circumference in respondents $(n=82)$

\begin{tabular}{|c|c|c|c|}
\hline \multirow[t]{4}{*}{ Biochemical marker } & \multicolumn{2}{|c|}{ Waist Circumference $(\mathrm{cm})$} & \multirow[t]{4}{*}{$\mathrm{P}$ value } \\
\hline & $\operatorname{Normal}(<90 \mathrm{~cm})$ & Obese $(>90 \mathrm{~cm})$ & \\
\hline & $(n=5)$ & $(\mathrm{n}=77)$ & \\
\hline & Mean \pm SD & Mean \pm SD & \\
\hline S. adiponectin $(\mu \mathrm{g} / \mathrm{ml})$ & $9.8 \pm 0.1$ & $9.1 \pm 0.6$ & 0.011 \\
\hline
\end{tabular}

$P$ value reached from unpaired t-test

Table V observed that mean S. adiponectin level was statistically significant between normal and obese person.

Table VI

Values of the biochemical marker according to the treatment modalities of DM in respondents $(n=82)$

\begin{tabular}{|c|c|c|c|c|c|}
\hline \multirow[t]{2}{*}{ Biochemical parameter } & \multicolumn{4}{|c|}{ Treatment of DM } & \multirow{2}{*}{$\begin{array}{c}\mathrm{P} \\
\text { value }\end{array}$} \\
\hline & $\begin{array}{c}\text { Life Style } \\
\text { modificaion } \\
(\mathrm{n}=22) \\
\text { Mean } \pm \text { SD }\end{array}$ & $\begin{array}{l}\text { Metformin } \\
(\mathrm{n}=20) \\
\\
\text { Mean } \pm \text { SD }\end{array}$ & $\begin{array}{c}\text { Insulin } \\
(\mathrm{n}=20)\end{array}$ & $\begin{array}{c}\text { Metformin + } \\
\text { insulin } \\
(\mathrm{n}=20) \\
\text { Mean } \pm \mathrm{SD}\end{array}$ & \\
\hline S. adiponectin $(\mu \mathrm{g} / \mathrm{ml})$ & $9.6 \pm 0.21$ & $9.1 \pm 0.57$ & $8.7 \pm 0.71$ & $9.2 \pm 0.21$ & 0.001 \\
\hline
\end{tabular}

$\mathrm{P}$ value reached from ANOVA test

This table showed that level of S. adiponectin were significantly lower in only insulin treated group than other groups.

\section{Table VII}

Values of the biochemical marker among only Metformin treated respondents according to BMI

\begin{tabular}{lcccc}
\hline Biochemical parameter & \multicolumn{3}{c}{ BMI $(\mathrm{Kg} / \mathrm{m} 2)$} & $\begin{array}{c}\mathrm{P} \\
\text { value }\end{array}$ \\
\cline { 2 - 4 } & $\begin{array}{c}18.5-24.9 \\
(\mathrm{n}=5)\end{array}$ & $\begin{array}{c}25-29.9 \\
(\mathrm{n}=6) \\
\text { Mean } \pm \mathrm{SD}\end{array}$ & $\begin{array}{c}\geq 30.0 \\
(\mathrm{n}=9)\end{array}$ & \\
\hline S. adiponectin $(\mu \mathrm{g} / \mathrm{ml})$ & $9.5 \pm 0.3$ & $9.3 \pm 0.4$ & $8.5 \pm 0.3$ & 0.001 \\
\hline
\end{tabular}

$P$ value reached from ANOVA test 
It was observed that mean S. adiponectin was significantly high in normal weight patients when compared with obese subjects.

\section{Discussion}

This retrospective cohort study was carried out with 82 post mastectomy female diabetic patients to evaluate the effects of metformin on S. adiponectin level.

In this present study it was observed that majority $(42.7 \%)$ respondents belonged to age 45-54 years, mean age was found 47.2 years. Similarly, Plengpanich et al. and Muti et al. had found that the mean age was 43.11 years and 44.8 years respectively ${ }^{33,30}$. On the other hand the mean age was 56 years ranged from 18103 years, which was higher than current study ${ }^{34}$. Similarly another study Yu et al. found the mean age was 60 years ${ }^{35}$. In this current study it was observed that $11.0 \%$ respondents had known positive family history.

In this study it was observed that $51.2 \%$ respondents were overweight and mean BMI was $28.4 \mathrm{~kg} / \mathrm{m}^{2}$ - which was closely resembled with the study of Duggan et $\mathrm{al}^{36}$. However, Plengpanich et al. study reported the mean BMI was $23.6 \mathrm{~kg} / \mathrm{m}^{2} 33$. Mean waist circumference was found $95.2 \mathrm{~cm}$.

S. adiponectin levels did not differ significantly in different age groups. This observation was consistent with the study carried out by Plengpanich et $\mathrm{al}^{33}$. But $\mathrm{S}$. adiponectin level differed significantly when compared with different BMI groups. Low levels of S. adiponectin with increasing BMI were evident in this study. Similar observation was reported in Duggan et $\mathrm{al}^{36}$. High level of S. adiponectin was associated with improved breast cancer survival with controlled blood glucose $(<126 \mathrm{mg} /$ d1) level and with a BMI $<25 \mathrm{~kg} / \mathrm{m}^{2}$. They concluded that low level of S. adiponectin were associated with obesity and increased breast cancer mortality.

It was evident from this study that $\mathrm{S}$. adiponectin level were low in $\mathrm{WC}>90 \mathrm{~cm}$ when compared with normal waist circumference. Tian YF et al. study resulted that increasing WC was significantly associated with higher risk in breast cancer patient when adjusted the plasma level of S. adiponectin ${ }^{26}$.
It was observed that mean S. adiponectin was statistically significant when compared with different modalities of DM treatment. Level of S. adiponectin were significantly lower in only insulin treated patient than other groups. It was also evident that metformin treated patients were significantly associated with higher S. adiponectin level.

In only metformin treated patients, S. adiponectin level differed significantly in various BMI categories. The study also showed significant negative correlation between $\mathrm{S}$. adiponectin and BMI. Duggan et al. suggested that BMI was inversely correlated with S. adiponectin levels in overweight or obese patients ${ }^{36}$.

\section{Conclusion}

It was evident from the study that $\mathrm{S}$. adiponectin was high in metformin treated post mastectomy female diabetic patients then treatment by insulin alone. Through this actions on biochemical marker metformin play an important role for prevention of recurrence in post mastectomy female patients.

\section{Referrences:}

1. GLOBOCAN, 2012. Cancer Fact Sheets: Breast cancer. [online] Available at:http://globocan.iarc.fr/ old/FactSheets/cancers/breast-new.asp. [Accessed 10 January, 2015].

2. NICRH Bangladesh, 2012. Cancer Registry: Breast cancer patients on rise. [online] Available at: http:// nicrhbd.org/details.php?sec $=1 \&$ cid $=4 \&$ id $=17430$. [Accessed 12 January, 2015].

3. NICRH Bangladesh, 2013. Cancer Registry: Breastc a n cer-ki11s - 8396 - wo me n - a - ye a r - in bangladesh.[online] Available at: http:// greenwatchbd.com. [Accessed 12 January, 2015].

4. Normans. Williams; Christopher J.K. Buldtrode \& P. Ronan O'Connell; Bailey \& Love's - Short Practice of Surgery $-26^{\text {th }}$ Edition, 2013 p.808,812. ISBN- 13(ISE) 978- 1- 4441- 2128- 5.

5. Liedtke C, Mazouni C, Hess KR et al. Response to neoadjuvant therapy and longterm survival in patients with triple-negative breast cancer. J Clin Oncol 2008;26:1275-1281.

6. Carey LA, Dees EC, Sawyer L et al. The triple negative paradox: primary tumor chemosensitivity of breast cancer subtypes. Clin Cancer Res 2007; 13:23292334. 
7. Gerard M. Doherty; Current Diagnosis \& Treatment Surgery $-13^{\text {th }}$ Edition, 2010, p.301,302. ISSN: 0894227.

8. European Cancer Organization (ECCO). 27 September 2013. "Diabetes increases risk of developing and dying from breast and colon cancer." ScienceDaily. ScienceDaily.[online] Available at: www. sciencedaily. com /releases /2013/09 / 130927183123.htm. [Accessed 7 January, 2015].

9. Knowler WC, Barrett-Connor E, Fowler SE, et al. Reduction in the incidence of type 2 diabetes with lifestyle intervention or metformin. $\mathrm{N}$ Engl J Med 2002;346:393-403.

10. Drugs.com: Metformin. 2011. [online] Available at: http://www.drugs.com/ pro/metformin.html. [Accessed 10 January, 2015].

11. Gonzalez-Angulo AM, Meric-Bernstam F. Metformin: A therapeutic opportunity in breast cancer. Clin Cancer Res 2010;16:1695-1700

12. Zhou G, Myers R, Li, et al: Role of AMPactivated protein kinase in mechanism of metformin action. $\mathrm{J}$ Clin Invest 2001;108:1167-1174.

13. Shackelford DB, Shaw RJ: The LKB1-AMPK pathway: Metabolism and growth control in tumour suppression. Nat Rev Cancer 2009;9:563-575.

14. GoDARTS and UKPDS Diabetes Pharmacogenetics Study Group, Wellcome Trust Case Control Consortium 2, Zhou K, et al: Common variants near ATM are associated with glycemic response to metformin in type 2 diabetes. Nat Genet 2011;43:117120.

15. Zakikhani M, Dowling R, Fantus IG, et al: Metformin is an AMP kinase-dependent growth inhibitor for breast cancer cells. Cancer Res 2006;66:1026910273.

16. Algire $\mathrm{C}$, Amrein L, Bazile M, et al: Diet and tumor LKB1 expression interact to determine sensitivity to anti-neoplastic effects of metformin in vivo. Oncogene 2011;30:1174-1182.

17. Michelle D Holmes and Wendy Y Chen. Hiding in plain view: the potential for commonly used drugs to reduce breast cancer mortality. Breast Cancer Research. 2012;14(6):216. doi:10.1186/bcr3336.

18. Belfiore A, Frasca F, Pandini G et al. Insulin receptor isoforms and insulin receptor/insulin-like growth factor receptor hybrids in physiology and disease. Endocr Rev 2009, 30:586-623.

19. Pollack MN. Insulin, insulin-like growth factors, insulin resistance, and neoplasia. Am J Clin Nutr 2007;86:s820-s822.

20. Chen DC, Chung YF, Yeh YT, Chaung HC, Kuo FC, Fu OY, Chen HY, Hou MF, Yuan SS: Serum adiponectin and leptin levels in Taiwanese breast cancer patients. Cancer Lett 2006;237:109-114.

21. Cust AE, Stocks T, Lukanova A, Lundin E, Hallmans G, Kaaks R, Jonsson H, Stattin P: The influence of overweight and insulin resistance on breast cancer risk and tumour stage at diagnosis: a prospective study. Breast Cancer Res Treat 2009;113:567-576.
22. Hou WK, Xu YX, Yu T, Zhang L, Zhang WW, Fu CL, Sun Y, Wu Q, Chen L: Adipocytokines and breast cancer risk. Chin Med J (Engl) 2007, 120: 1592-1596.

23. Korner A, Pazaitou-Panayiotou K, Kelesidis T, Kelesidis I, Williams CJ and Kaprara A, et al.: Total and high-molecular-weight adiponectin in breast cancer: in vitro and in vivo studies. J Clin Endocrinol Metab 2007;92:1041-1048.

24. Mantzoros C, Petridou E, Dessypris N, Chavelas C, Dalamaga M, Alexe DM, Papadiamantis Y, Markopoulos C, Spanos E, Chrousos G, Trichopoulos D: Adiponectin and breast cancer risk. J Clin Endocrinol Metab 2004;89:1102-1107.

25. Miyoshi Y, Funahashi T, Kihara S, Taguchi T, Tamaki Y, Matsuzawa Y, Noguchi S: Association of serum adiponectin levels with breast cancer risk. Clin Cancer Res 2003;9: 5699-5704.

26. Tian YF, Chu CH, Wu MH, Chang CL, Yang T, Chou YC, Hsu GC, Yu CP, Yu JC, Sun CA. Anthropometric measures, plasma adiponectin, and breast cancer risk. Endocr Relat Cancer 2007;14: 669-677.

27. Tworoger SS, Eliassen AH, Kelesidis T, Colditz GA, Willett WC, Mantzoros CS, Hankinson SE: Plasma adiponectin concentrations and risk of incident breast cancer. J Clin Endocrinol Metab 2007;92:1510-1516.

28. Kang JH, Yu BY, Youn DS: Relationship of serum adiponectin and resistin levels with breast cancer risk. J Korean Med Sci 2007;22:117-121.

29. Lawlor DA, Smith GD, Ebrahim S: Hyperinsulinaemia and increased risk of breast cancer: Findings from the British Women's Heart and Health Study. Cancer Causes Control. 2004; 15:267-275.

30. Muti P, Quattrin T, Grant BJ, et al: Fasting glucose is a risk factor for breast cancer: A prospective study. Cancer Epidemiol Biomarkers Prev. 2002;11:13611368.

31. Del Giudice ME, Fantus IG, Ezzat S, et al: Insulin and related factors in premenopausal breast cancer risk. Breast Cancer Res Treat. 1998;47:111-120.

32. Gunter MJ, Hoover DR, Yu H, et al: Insulin, insulin like growth factor-I, and risk of breast cancer in postmenopausal women. J Natl Cancer Inst. 2009;101:48-60.

33. Plengpanich W, Mangkala J, Buranasukajorn P, Boonruang K, Sunthornyothin S, Suwanwalaikorn $\mathrm{S}$ et al. Normal Reference Range of Serum InsulinLike Growth Factor (IGF)-I in Healthy Thai Adults. J Med Assoc Thai 2008; 91 (11): 1681-4.

34. Soffer D, Shi J, Chung J, Schottinger JE, Wallner LP, Chlebowski RT et al. Metformin and breast and gynecological cancer risk among Women with diabetes. Diabetes Research and Care 2015; 3:e000049.

35. Yu H, Levesque MA, Khosravi MJ, Diamandi P, Clark GM and Diamandis EP: Insulin-like growth factorbinding protein-3 and breast cancer survival. Int. J. Cancer (Pred. Oncol.)1998; 79:624-28.

36. Duggan C, Melinda L, Irwin et al: Association of insulin resistance and adiponectin with mortality in women with breast cancer. Journal of clinical oncology 2010; 10.1200. 